\begin{tabular}{lrr}
\hline \hline VOLUME 2 & No. 1 (April 2019) & Page 20-30 \\
\hline \hline
\end{tabular}

\title{
Analisis Wacana Kritis Berita Politik dalam Surat Kabar Koran Kaltim
}

\author{
Jihan Alfira, Widyatmike Gede Mulawarman, Syamsul Rijal \\ Universitas Mulawarman \\ Universitas Mulawarman \\ Universitas Mulawarman \\ Email: jhnalfiraaa@gmail.com
}

\begin{abstract}
This study aims to describe the form of language expression and the political news discourse perspective of Koran Kaltim using Roger Fowler's model. In using Roger Fowler's analysis, clarification can be seen how the same event is translated into different languages. These different words are not seen as technical but are seen as an ideological practice. This type of research is a qualitative descriptive study. Sources of data used in this research are journalistic products of printed mass media, namely Koran Kaltim. Data collection techniques are reading, listening, and note-taking techniques. The data presentation technique in this study contains an explanation of the forms of language expression and perspective. Overall the results of the study show the following two conclusions. First, the forms of language expression based on political news discourse modalities include necessity modality, desire modality, truth modality as well as various types of metaphors. This form of language expression represents the views, values, ideas and beliefs of journalists in the Kaltim newspaper. Second, the pro-government perspective dominates the political news in the Kaltim newspaper.
\end{abstract}

Keywords: critical discourse analysis, modalities, perspectives.

\section{PENDAHULUAN}

Bahasa merupakan suatu ungkapan yang mengandung maksud untuk menyampaikan sesuatu kepada orang lain. Sesuatu yang dimaksudkan oleh pembicara bisa dipahami dan dimengerti oleh pendengar atau lawan bicara melalui bahasa yang diungkapkan. Dengan adanya bahasa kita dapat dengan mudah berinteraksi dengan manusia lainnya.

Wacana merupakan satuan bahasa tertinggi dalam tataran linguistik. Wacana dapat berupa lisan dan tulisan. Wacana juga merupakan bentuk pengungkapan pikiran dan gagasan yang berkembang di masyarakat. Khususnya wacana tulis perlu dianalisis atau dikaji secara kritis oleh pemakai bahasa karena wacana digunakan untuk mengkaji segala informasi yang berguna bagi pembaca. Pembaca dapat mengetahui isi atau fenomena yang sedang terjadi di berbagai tempat dengan adanya wacana. Selain itu, kata wacana bahkan dijadikan untuk menyatakan suatu informasi yang belum jelas kebenarannya. Untuk memperjuangkan ideologi yang dianut, maka secara langsung atau tidak langsung penulis juga memarjinalisasi ideologi yang lain. Oleh karena itu, pembaca yang kritis dapat memahami wacana dari sudut pandang yang berbeda dengan menerapkan analisis wacana kritis dalam mengkaji fenomena yang terjadi. Analisis wacana kritis model Roger Fowler dkk dapat digunakan untuk melihat bagaimana cara media dalam mengontruksi suatu pemberitaan. Fowler dkk (dalam Eriyanto 2011:134) membagi empat fungsi kosakata, yakni (1) kosakata sebagai klarifikasi, (2) kosakata sebagai pembatas pandangan, (3) kosakata 
pertarungan wacana, (4) kosakata sebagai marjinalisasi. Dalam analisis Roger Fowler mengungkapkan bahwa klarifikasi dapat dilihat bagaimana peristiwa yang sama dibahasakan dengan bahasa yang berbeda.

Bagi analisis wacara krisis, wacana merupakan praktik sosial yang menyusun dunia sosial dan disusun oleh praktik-praktik sosial yang lain. Wacana tidak hanya memberikan kontribusi pada pembentukan kembali struktur sosial namun merefleksasikan pembentukan kembali struktur sosial tersebut. Louis Althusser (dalam Sobur, 2015: 30) menulis bahwa media, dalam hubungannya dengan kekuasaan, menempati posisi stragis, terutama karena anggapan akan kemampuannya sebagai sarana legitimasi.

Sebagai suatu alat untuk menyampaikan berita, penilaian, atau gambaran umum tentang banyak hal, media mempunyai kemampuan untuk berperan sebagai institusi yang dapat membentuk opini publik, antara lain karena media juga dapat berkembang menjadi kelompok penekan atas suatu ide atau gagasan, dan bahkan suatu kepentingan atau citra yang media representasikan untuk diletakkan dalam konteks kehidupan yang lebih empiris. Salah satu bentuk penyajian wacana oleh media massa adalah berita, baik berita tulis yang bisa ditemui dalam majalah, surat kabar, tabloid, maupun berita yang disampaikan lisan melalui siaran radio dan televisi.

Istilah wacana kritis tidak hanya mengemukakan makna dari kajian bahasa, tetapi juga digunakan di dalam lapangan kajian apapun dengan menyertakan telaah bahasa di dalam pemakaiannya dalam kajian psikologi sosial, analisis wacana merujuk pada kajian terhadap struktur dan bentuk percakapan atau wawancara (Yunisa Oktavia, 2016:203). Dalam kajian ilmu politik, analisis wacana merujuk pada kajian terhadap praktik pemakaian bahasa dan hubungannya dengan kekuasaan terutama di dalam teks berita. Pemahaman dasar analisis wacana kritis adalah wacana tidak dipahami semata-mata sebagai objek studi bahasa atau dipandang di dalam pengertian linguistik tradisional, tetapi bahasa di dalam analisis wacana kritis dipahami sebagai alat yang dipakai untuk tujuan dan praktik tertentu termasuk praktik ideologi dan kekuasaan.

Secara sosiologis, berita adalah semua hal yang terjadi di dunia. Dalam gambaran yang sederhana, seperti dilukiskan dengan baik oleh para pakar jurnalistik, berita adalah apa yang ditulis surat kabar, apa yang disiarkan radio, dan apa yang ditayangkan di televisi. Berita menampilkan fakta, tetapi tidak semua fakta merupakan berita. Berita biasanya menyangkut orang-orang, tetapi tidak setiap orang bisa dijadikan berita. Berita merupakan sejumlah peristiwa yang terjadi di dunia, tetapi hanya sebagian kecil saja yang dilaporkan.

Surat kabar saat terbit sering kali mengemukakan beberapa topik permasalahan, topik tersebut antara lain politik, ekonomi, sosial, budaya, dan lain-lain. Di Samarinda khususnya, surat kabar yang sering dijumpai ialah Koran Kaltim. Adanya Koran Kaltim yang mempublikasi berita tentang keadaan Kalimantan Timur membuat pembaca mengetahui informasi terkini yang terjadi di Kalimantan Timur. Salah satu beragam berita yang disajikan dalam surat kabar tersebut adalah berita tentang politik.

Penggunaan bahasa dalam berita politik memiliki ciri yang khas, membuat bahasa dalam berita politik berbeda dengan bahasa berita yang lain. Salah satu ciri yang khas dalam berita politik adalah adanya penggunaan metafora dan modalitas di dalamnya. (Haula, $2010: 7$ ) metafora dewasa ini tidak hanya terdapat dalam ruang lingkup sastra saja, seperti puisi, novel, maupun film. Metafora juga banyak ditemukan dalam ruang lingkup nonfiksi, seperti dalam berita maupun artikel.

Berdasarkan topik di atas mengenai bentuk-bentuk ekspresi bahasa dan perspektif wacana berita politik, penelitian terkait dengan analisis wacana kritis seperti yang dilakukan oleh Yunisa Oktavia (2016) dalam judul "Implementasi Analisis Wacana Kritis Prespektif Leeuwen dalam Berita Politik Surat Kabar Padang Ekspres Terhadap Pembelajaran Bahasa Berbasis Teks". Selanjutnya penelitian yang terkait dengan ideologi pernah dilakukan oleh Suharyo (2012) dalam judul "Mengungkap Ideologi dan Kekuasaan Simbolik di Balik Penggunaan Bahasa". Beberapa penelitian di atas menekankan analisis wacana dalam surat kabar, baik wacana hukum, maupun wacana politik. Sementara itu, penelitian yang mengarah kepada analisis wacana berita politik surat kabar Koran Kaltim dengan menggunakan teori pendekatan kritis, sejauh ini belum ditemui oleh peneliti. Dengan berpijak kepada penelitian terdahulu, muncul ide peneliti untuk mengungkap bentukbentuk ekspresi bahasa dan perspektif dari sebuah wacana berita, khususnya berita politik dengan menggunakan analisis wacana kritis. Peneliti menggunakan analisis wacana kritis karena wacana tidak hanya dipahami sebagai studi mengenai aspek kebahasaan saja, melainkan dihubungkan dengan konteks wacana yang ada, termasuk di dalamnya tujuan tertentu dari praktik kekuasaan. Analisis wacana kritis digunakan untuk membongkar kekuasaan dalam setiap proses bahasa, antara lain 
batasan-batasan yang diperkenankan menjadi wacana, dan perspektif yang dipakai.

Dengan latar belakang yang telah dipaparkan ini, maka tujuan penelitian ini dapat diidentifikasi sebagai berikut:

Mendeskripsikan ekspresi-ekspresi bahasa yang muncul dalam wacana berita politik surat kabar Koran Kaltim (2) Mendeskripsikan perspektif yang muncul dalam wacana berita politik surat kabar Koran Kaltim.

Adapun permasalahan yang menjadi

kajian dalam penelitian ini yaitu, (1) Bagaimanakah ekspresi-ekpresi bahasa yang muncul dalam berita politik surat kabar iKoran Kaltim? (2) Bagaimanakah perspektif yang muncul dalam berita politik surat kabar Koran Kaltim?.

Analisis wacana kritis (sering disebut AWK) menyediakan teori dan metode yang bisa digunakan untuk melakukan empiris tentang hubungan-hubungan antara wacana dan perkembangan sosial dan kultural dalam domaindomain sosial yang berbeda (Marianne 2010:114). Analisis wacana kritis menurut (Darma, 2009:49) merupakan sebuah upaya atau proses penguraian untuk memberikan kejelasan dari sebuah teks (realitas isosial) yang mau atau sedang dikaji oleh seseorang atau kelompok dominan yang mempunyai tujuan tertentu untuk memperoleh apa yang diinginkan. Analisis wacana kritis mengkaji tentang upaya kekuatan sosial, dominasi, dan kepentingan yang direproduksi dan dipertahankan melalui teks yang pembahasannya dihubungkan dengan sosial dan politik yang mempunyai tujuan asumsi.

Perspektif suatu ideologi dipengaruhi secara sistematis pada pemikiran bentuk-bentuk ekspresi lingustik, seperti pemakaian kosakata, tindak tutur, metafora dan modalitas. Dari beberapa bentuk ekspresi tersebut yang diteliti ialah modalitas dan metafora.

1. Modalitas, Menurut Bally (dalam Abdulrahman, 2011:3), modalitas sebagai bentuk bahasa yang menggambarkan penilaian berdasarkan penalaran, penilaian berdasarkan rasa, atau keinginan pembicara sehubungan dengan persepsi atau pengungkapan jiwanya. Modalitas oleh Fowler (dalam Puspito, 2018:35) dimengerti sebagai komentar atau perspektif, yang berasal dari teks, baik secara eksplisit atau implisit diberikan oleh penulis terhadap hal yang dilaporkan, yakni keadaan, peristiwa dan tindakan. Modalitas sebagai komentar atau perspektif dari penulis yang tertuang dalam teks dapat dibagi menjadi empat jenis, yakni (1) kebenaran, (2) keharusan, (3) keinginan.

2. Metafora, Menurut (Eriyanto, 2011:59), seorang wartawan tidak hanya menyampaikan pesan pokok lewat teks, tetapi juga kiasan, ungkapan, metafora yang dimaksud sebagai ornamen atau bumbu dari suatu berita. Akan tetapi, pemakaian metafora tertentu bisa jadi menjadi petunjuk utama untuk mengerti suatu teks. Metafora tertentu dipakai oleh wartawan secara strategis sebagai landasan berpikir, alasan pembenar atas pendapat atau gagasan tertentu kepada publik. Wartawan menggunakan kepercayaan masyarakat, ungkapan sehari-hari, peribahasa, pepatah, petuah leluhur, kata-kata kuno, bahkan mungkin yang diambil dari ayat-ayat suci yang semuanya dipakai untuk meperkuat pesan utama.

Dalam menulis wacana berita, perspektif dibangun sejak penulis memutuskan apa yang dipilih sebagai tema dalam tulisannya. Perspektif atau sudut pandang penulis dapat dipengaruhi oleh praktik sosial tertentu. (Suroso, 2002:100), dalam melaporkan suatu peristiwa, wartawa secara sadar maupun tidak sadar memberikan penilaianpenilaian sebagai ekspresi dari apa yang diyakini. Oleh karena itu, penulis atau wartawan dianggap sebagai pihak tidak netral dalam mengolah dan memproduksi bahasa di dalam pernyataan. Tidak sedikit wacana berita yang bersifat provokatif dan merugikan pihak lain sehingga perlu mengkaji tulisan lebih dalam untuk membongkar kuasa yang ada dalam setiap proses bahasa agar mengetahui dan memahami makna yang terkandung di dalamnya.

Subjek dalam penelitian ini adalah berita politik yang ada dalam surat kabar Koran Kaltim Edisi Januari 2020. Subjek ini diambil melalui surat kabar Koran Kaltim yang terbit setiap hari. Data dalam penelitian ini berupa wacana berita politik surat kabar Koran Kaltim Edisi Januari 2020. Objek penelitian ini adalah bentuk ekspresi bahasa wacana berita politik serta perspektif pemberitaan wacana berita politik surat kabar Koran Kaltim. Dalam penelitian ini wujud data berupa teks berita politik secara keseluruhan dan kalimat yang terdapat dalam teks. Wujud data pertama yang berupa kalimat digunakan untuk mengungkap objek penelitian berupa bentuk ekspresi bahasa. Wujud data kedua berupa teks berita politik digunakan untuk mengungkap objek penelitian perspektif pemberitaan. Sumber data ini adalah tertulis berupa bahasa tulis yang terdapat 
dalam surat kabar Koran Kaltim Edisi Januari 2020.

Metode yang digunakan ialah metode kualitatif. Moleong (2017 :6) menjelaskan bahwa penelitian deskriptif kualitatif adalah penelitian yang mendeskripsikan suatu objek penelitian yang berupa kutipan data sebagai gambaran penyajian laporan penelitian. Penelitian kualitatif sebagai penelitian untuk memahami fenomena yang di alami oleh subjek penelitian, misalnya perilaku, persepsi, motivasi, tindakan secara holistik dan dengan cara deskripsi dalam bentuk kata-kata dan bahasa pada suatu konteks khusus yang alamiah dan dengan memanfaatkan berbagai metode ilmiah.

Pengumpulan data dalam penelitian terhadap wacana berita politik yang terdapat dalam surat kabar Koran Kaltim ini menggunakan metode simak dengan teknik baca dan teknik catat. Digunakan metode simak karena memang merupakan penyimakan terhadap wacana. Teknik baca digunakan karena dalam memperoleh data dilakukan kegiatan membaca. Teknik selanjutnya, adalah teknik catat yaitu menjaring data dengan mencatat hasil penyimakan data. Tahapan yang dilakukan dalam pengumpulan data: (1) mencari berita dalam surat kabar Koran Kaltim mulai dari tanggal 1 Januari sampai 31 Januari 2020, (2) memilih topik berita politik, (3) memilih data secara acak dengan mengambil satu data per harinya untuk dijadikan sampel, (4) membaca dan mencatat data ke dalam kartu data.

Teknik analisis data yang digunakan dalam penelitian ini adalah teknik deskriptif kualitatif. Langkahnya adalah (1) mendeskripsikan bentuk ekspresi bahasa wacana berita politik, (2) mengelompokkan data berdasarkan bentuk ekspresi bahasa, (3) mendeskripsikan perspektif wacana berita tersebut, (4) menganalisis perspektif wacana berita politik.

\section{PENYAJIAN DATA DAN PEMBAHASAN}

Pada penelitian ini modalitas yang digunakan untuk menjabarkan penjelasan tentang tiga bagian dari modalitas ialah modalitas kebenaran, modalitas keharusan, dan modalitas keinginan. Modalitas kebenaran dalam hal ini seorang wartawan menyatakan secara tidak langsung tentang kebenaran suatu proposisi yang ditulis dan suatu prediksi tingkat kemungkinan yang diberikan merupakan indikator untuk mengungkap suatu kebenaran peristiwa yang dilaporkan. Dengan menggunakan modalitas kebenaran dapat di berikan penilaian dari suatu pernyataan dari kejadian atau peristiwa yang sedang dilaporkan. Bentuk ekspresi yang digunakan untuk mendukung kebenaran ini adalah dari bahasa yang dituliskan oleh wartawan sebagai pembuat berita.

Bentuk ekspresi yang digunakan untuk mendukung keinginan ini adalah dari bahasa yang di tuliskan oleh wartawan sebagai pembuat berita. Keinginan tersebut dibuat dengan realitas dan kondisi dalam peristiwa yang sedang terjadi, yang apa adanya tanpa mengubah fakta yang ada. Bentuk ekspresi bahasa yang kedua adalah metafora digunakan sebagai alat untuk mengibaratkan suatu objek dengan cara analogi, dideskripsikan ke dalam kalimat dengan melalui pemakaian metafora. Kedua bentuk ekspresi bahasa tersebut sebagai berikut.

(08/01) Plt Badan Pendapatan Pajak dan Retribusi Daerah (BPPRD) Balikpapan, Haemusri Umar menyebut pihaknya telah memiliki strategi untuk menggenjot pendapatan pajak yang pada tahun ini di target Rp515 miliar...

a) Modalitas: Data (08/01) modalitas dengan kata telah menjelaskan peristiwa yang sudah terjadi, yakni kebenaran dan keyakinan Haemusri Umar tentang strategi yang dimilikinya untuk meningkatkan pendapatan pajak tahun ini.

b) Metafora: Data (08/01) ditemukan penggunaan metafora dalam kata menggenjot memberikan penilaian yang netral terhadap Haemusri Umar karena sudah memiliki startegi yang dapat meningkatkan pendapatan pajak.

(09/01) Sementara Ketua DPC Partai Haruna Kota Balikpapan, Syarifudin Odang menyebut keputusan pengusungan tentu harus menyesuaikan mekanisme dan Peraturan Organisasi. "Kami sepakat memutuskan Ahmad Basir untuk direkomendasikan dan diajukan ke DPP. Nanti DPP yang mengeluarkan surat rekomendasi," terangnya. Diaberharap bahwa dengan adanya pemimpin yang baru, Balikpapan dapat lebih maju, mengingat Balikpapan menjadi penyangga $\mathrm{Ibu}$ Kota Negara (IKN)...

a) Modalitas: Data (09/01) modalitas dengan kata berharap menunjukkan keinginan dari Syarifuddin Odang dengan adanya pemimpin yang baru dapat menjadikan Balikpapan lebih maju. Ini ditunjukkan dari sikap wartawan yang terlibat dari pengunaan modalitas berharap. Sikap demikian dapat diketahui pada saat wartawan mengatakan harapan dari Syafudin Odang agar Balikpapan menjadi lebih maju karena 
adanya pemimpin yang baru.

b) Metafora: Data (09/01) ditemukan penggunaan metafora dalam kata penyangga ini memberikan penilaian yang netral terhadap kota Balikpapan yang diharapkan dengan adanya pemimpin yang baru, Balikpapan menjadi lebih maju. Balikpapan diibaratkan sebagai tiang yang dapat dijadikan sebagai sandara.

(10/01) Catatan Hitam dalam Pemilu 2019 lalu, menjadi tamparan keras bagi Komisi Pemilihan Umum (KPU) Kota Samarinda, di mana anggota Panitia Pemilihan Kecamatan (PPK) harusmenjalani pidana lantaran terbukti mengalihkan suara usai pemilihan...

a) Modalitas: Data (10/01) wartawan menggunakan modalitas pada kata harus untuk menunjukkan adanya suatu keharusan mengenai anggota Panitia Pemilihan Kecamatan (PPK) untuk menjalani pidana. Modalitas harus menunjukan suatu kewajiban yang harus segera dilakukan oleh anggota Panitia Pemilihan Kecamatan (PPK) yaitu menjalani pidana karena terbukti mengalihkan suara usai pemilihan.

b) Metafora: Data (10/01) penggunaan kata catatan hitam memberikan penilaian negatif terhadap Pemilu 2019, karena dalam Pemilu tersebut terdapat anggota PPK yang tidak jujur dalam menjalankan tugasnya. Metafora dalam kata Itamparan keras memberikan penilaian negatif terhadap Komisi Pemilihan Umum (KPU) Kota Samarinda. Hal ini dikarenakan anggota Panitia Pemilihan Kecamatan (PPK) terbukti mengalihkan suara usai pemilihan.

(11/01) Tahun ini bisa menjadi tahun tersibuk di Kabupaten Paser. Selain menggelar Pemilihan Kepala Daerah, Pemkab juga akan melaksanakan Pemilihan Kepada Desa (Pilkades) serentak...

a) Modalitas: Data (11/01) menjelaskan mengenai keinginan untuk melaksanakan Pemilihan Kepala Daerah dan Kepala Desa secara serentak. Hal ini menunjukkan sikap wartawan yang terlihat dari penggunaan modalitas yakni kata akan. Sikap ini dapat diketahui pada saat wartawan mengatakan tahun ini bisa menjadi tahun tersibuk di Kabupaten Paser. Karena Pemilihan KepalaDaerah dan Kepala Desa hendak dilakukan secara serentak.

b) Metafora: Data (11/1) penggunaan kata metafora dalam kata menggelarmemberikan penilaianyang netral terhadap Pemilihan KepalaDaerah dan Kepala Desa. Pelaksanaan Pilkada tersebut diibaratkan seperti kain yang luas.

(15/01)...Sebelum bersama Aneha, Markus sendiri mengaku sempat melirik jalur partai, yaitu Nasdem. Namun ia menegaskan, komitmen untuk maju di jalur independen kini sudah merupakan pilihan politiknya. Ia siap melepaskan kesempatan maju lewat perahu partai, meski nanti mendapat rekomendasi dari Nasdem...

a) Modalitas: Data (15/01) modaitas dengan kata sudah menjelaskan mengenai kebenaran komitmen dari Markus untuk maju di Pilada melalui jalur independen.

b) Metafora: Data (15/01) penggunaan kata metafora dalam kata perahumemberikan penilaian yang netral terhadap komitmen Markus yang siap melepaskan kesempatan maju lewat bantuan partai, meski nanti mendapat rekomendasi dari Nasdem. Partai diibaratkan seperti benda yang dapat ditumpangi.

(16/01) Sebagian besar partai politik yang memiliki kursi di DPRD Kutai Kartanegara (Kukar) telah jauh hari membuka penjaringan bakal calon (bacalon) bupati maupun wakil bupati (wabup) yang akan diusung di Pemilihan Kepala Daerah (Pilkada) September mendatang...

a) Modalitas: Data (16/01) modalitas dengan kata telah menjelaskan mengenai kebenaran bahwa sebagian besar partai politik yang memiliki kursi di DPRD Kukar sudah menyeleksi bacalon bupati maupun wakil bupati yang akan diusung di Pilkada September mendatang.

b) Metafora: Data (16/01) penggunaan metafora dalam kata penjaringan memberikan penilaian yang netral terhadap seleksi yang dilakukan oleh partai politik yang memiliki kursi di DPRD Kukar. Penyeleksian tersebut diibaratkan seperti alat untuk menangkap sesuatu.

(17/01)...Jika nanti Isran yang memegang kendali Golkar Kaltim, ada kemungkinan isran akan menunjuk calonnya sendiri di Kukar dengan prediksi koalisi Golkar, PDIP, dan Gerindra...

a) Modalitas: Data (17/01) penggunaan modalitas akan menunjukkan keinginan dari Isran Noor yang ingin menunjukkan calonnya sendiri jika Isran menguasai Golkar Kaltim.

b) Metafora: Data (17/01) penggunaan 
modalitas dalam kata memegang kendali memberikan penilaian yang netral terhadap Isran Noor karena terdapat kemungkinan jika Isran Noor dapat menguasai Golkar Kaltim, maka Isran Noor akan menunjukan calonnya sendiri. Partai GolkarKaltim diibaratkan seperti benda yang dapat dikendalikan.

(18/01)...Semantara untuk di Samarinda, nama ASN yang disinyalir juga mendaftar maju di Pilkada itu rupanya juga telah lama menjadi bidikan Bawaslu...

a) Modalitas: Data (18/01) penggunaan modalitas telah menunjukkan kebenaran bahwa nama Aparatur Sipil Negara (ASN) yang mendaftar maju Pilkada sudah lama diperhatikan oleh Badan Pengawas Pemilu (Bawaslu).

b) Metafora: Data (18/01) penggunaan modalitas dalam kata bidikan memberikan penilaian negatif terhadap nama Aparatur Sipil Negara (ASN) yang mendaftar maju Pilkada karena selain mendapat peringatan nama ASN tersebut sudah lama diperhatikan oleh Bawaslu.

(21/01)...Terutama pasca masuknya Bakal Calon (Bacalon) Bupati petahana, Edi Darmansyah yang mengincar perahu politik tiga partai ini untuk bisa menjadi bagian dari partai pengusungnya nanti...

a) Modalitas: Data (21/01) menjelaskan mengenai keinginan Edi Darmansyah agar tiga partai ( Partai Amanat Nasional, Partai Keadilan Sejahtera, dan Partai persatuan Pembangunan) bisa menjadi bagian dari partai pengusungnya nanti. Hal ini menunjukkan sikap wartawan yang terlihat dari penggunaan modalitas kata untuk.

b) Metafora: Dara (21/01) penggunaan metafora mengincar memberikan penilaian yang netral terhadap keinginan Edi Darmasnyah untuk menjadikan tiga partai tersebut sebagai pengusungnya.

(25/01)...Bukan karena kurang persyaratan, melainkan karena Heru Bambang yang juga mantan Wawali Balikpapan itu tersandung masalah hukum. Heru menjadi tersangka kasus pidana yang saat ini masih bergulir di meja hijau Pengadilan Negana (PN) Balikpapan...

a) Modalitas: Data (25/01) menggunakan modalitas saat ini menunjukkan suatu kebenaran bahwa Heru Bambang menjadi tersangka kasus pidana yang masih bergulir di meja hijau Pengadilan Negara (PN)
Balikpapan. Hal ini ditunjukkan dengan pemakaian kata saat ini yang secara tidak langsung menunjujjan kebenaran.

b) Metafora: Data (25/01) penggunaan metafora tersandung memberikan penilaian yang negatif terhadap Heru Bambang karena langkah pasangan calon tersebut terhalangan bukan karenakurang persyaratan, melainkan karena statusnya yang masih menjadi kasus pidana. Heru Bambang diibaratkan seperti terhalang benda.

(27/01) Satu per satu pasangan calon (paslon) yang akan bertarung di Pemilihan Kepala Daerah (Pilkada) Kutai Kartanegara (Kukar) September mendatang mulai kelihatan...

a) Modalitas: Data (27/01) menggunakan modalitas akan menunjukan keinginan dari pasangan calon yang akan maju di Pilkada Kutai Kartanegara September mendatang untuk mendeklarasikan diri dan pasangannya.

b) Metafora: Data (27/01) penggunaan metafora bertarung memberikan penilaian yang netral terhadap pasangan calon yang akan maju di Pilkada Kutai Kartanegara. Pilkada diibaratkan seperti sebuah pertandingan.

(28/01)...Andi Harun hanya memastikan selain Gerindra yang kini ia pimpin, kedua partai lainnya sebenarnya sudah cukup untuk mengusungnya buat berlaga dalam kontestasi politik di Pilkada Samarinda...

a) Modalitas: Data (28/01) menggunakan modalitas untuk menunjukan keinginan dari Andi Harun yang ingin memastikan selain Gerindra, terdapat dua partai lainnya yang sudah cukup mengusungnya di Pilkada Samarinda.

b) Metafora: Data (28/01) penggunaan metafora berlaga memberikan penilaian yang netral terhadap Andi Harun yang akan maju di Pilkada Samarinda. Pilkada diibaratkan seperti sebuah pertandingan.

(29/01)...Untuk keseriusan, Erwin mengaku tidak main-main. Dirinya sangat ingin memperbaiki Samarinda. Alasannya, Samarinda yang nantinya akan menjadi salah satu kota penyangga Ibu Kota Negara, dinilai harus menjadi tempat yang lebih baik lagi...

a) Modalitas: Data (29/01) menggunakan modalitas akan menunjukan keinginan dari Erwin untuk menjadikan Samarinda lebih baik lagi, karena Samarinda dinilai dapat 
menjadi salah satu kota yang membantu Ibu Kota Negara.

b) Metafora: Data (29/01) pengunaan metafora penyangga memberikan penilaianyang netral terhadap Samarinda yang dinilai dapat membantu Ibu Kota Negara. Samarinda diibaratkan sebagai tiang yang dapat dijadikan sebagai sandaran.

(30/01) Pasangan Bakal Calon (Bacalon) Wali Kota (Wawali) Samarinda, Andi Harun Rusmadi Wongso terus melenggeng ke permukaan...

a) Modalitas: Data (30/01) menggunakan modalitas terus menunjukkan kebenaran terhadap Andi Harun - Rusmadi Wongso yang maju sebagai pasangan Bakal Calon Wali Kota Samarinda.

b) Metafora: Data (30/01) pengunaan metafora melenggang memberikan penilaian yang netral terhadap Andi Harun - Rusmadi Wongso yang yang maju sebgai Bakal Calon Wali Kota Samarinda.

(31/01) Wakil Presiden (Wapres) Ma"ruf Amin membantah soal tudingan bahwa dirinya tak menonjol dalam membantu kerja Presiden Joko Widodo (Jokowi) selama 100 hari pemerintahannya...

a) Modalitas: Data (31/01) menggunakan modalitas tak menunjukkan kebenaran bahwa Maeruf Amin membantah bahwa dirinya tidak aktif dalam membantu kerja Presiden Joko Widodo (Jokowi) selama 100 hari pemerintahannya.

b) Metafora: Data (31/01) penggunaan metafora menonjol memberikan penilaian negatif terhadap Ma"ruf Amin yang dinilai tidak aktif dalam membantu kerja Presiden Joko Widodo (Jokowi) selama 100 hari pemerintahannya. Kinerja Maeruf Amin diibaratkan sebagai benda yang dapat dilihat.

Hasil penelitian terhadap perspektif menunjukkan bahwa pemberitaan surat kabar Koran Kaltim Januari 2020 meliputi perspektif promasyarakat, dan perspektif propemerintah. Data yang menunjukkan perspektif terbanyak ialah perspektif propemerintah sebanyak 29 kemunculan, sedangkan perspektif promasyarakat sebanyak 2 kemunculan. Data tersebut menunjukkan surat kabar

Koran Kaltim Januari 2020 banyak mengangkat wacana mengenai pemerintahan yakni salah satunya tentang pemilu. Hal tersebut di tunjukkan dengan sebanyak 29 kemunculan judul pemberitaan yang propemerintah. Banyaknya kemunculan mengenai topik, peristiwa, dan nada pemberitaan pada surat kabar Koran Kaltim, berita tentang pemilu menjadi wacana yang sering dan banyak diangkat dalam surat kabar. Hal ini dikarenakan pada bulan Januari banyak sekali partai-partai politik yang akan mengikuti pemilu 2020.

Perspektif propemerintah merupakan sudut pandang dalam melihat suatu peristiwa yang didasari oleh nilai-nilai keyakinan, ide-ide, dan pandangan pemerintah. Seorang wartawan dalam melaporkan suatu peristiwa dengan berdasarkan perspektif pro pemerintah pasti akan mempunyai sikap atau pandangan yang mendukung, memihak, dan senang terhadap setiap tindakan yang dilakukan oleh pemerintah. Berikut ini beberapa kutipan dari data.

Pada data (01/01) dengan judul "Satu Kursi Hanura Berau Ternyata Seksi" ditunjukkan sikap wartawan yang propemerintah.

Satu kursi milik Hanura di DPRD Berau ternyata memang benar-benar seksi. Buktinya, diperebutkan tiga kandidat Bakal Calon (Bacalon) Bupati Berau yang boleh dibilang sangat diperhitungkan. Di antaranya Bupati Berau Muharram, Wakil Bupati (Wabup) Berau Agus Tantomo, dan petinggi Partai Pesatuan Pembangunan (PPP) Kaltim Gamalis..(01/01)

Pada data diatas terdapat topik "Satu kursi milik Hanura di DPRD Berau ternyata benar-benar seksi". Wartawan memilih topik tersebut secara tidak langsung telah membenarkan bahwa kursi milik Hanura di DPRD diperebutkan oleh tiga kandidat Bakal Calon (Bacalon) Bupati Berau. Data (01/01) terdapat partisipan yaitu Bupati Berau Muharram, Wakil Bupati (Wabup) Berau Agus Tantomo, dan petinggi Partai Pesatuan Pembangunan (PPP) Kaltim Gamalis yang menjadi pusat perhatian pemberitaan. Dilihat dari nada pemberitaan, wartawan lebih banyak membahas persaiangan tiga kandidat tersebut yang memperbutkankursi Hanura di DPRD.

Pada data (03/01) dengan judul "Mayoritas DPC Dorong Jaang Dua Periode " ditunjukkan sikap wartawan yang propemerintah.

Meski Musyawarah Daerah (Musda) Partai Demokrat Kaltim masih dalam hitungan bulan, naun desas-desus soal upaya untuk mendorong Syaharie Jaang memimpin dua periode kini sudah mulai tercium...(03/01) 
Pada data di atas terdapat topik "Upaya untuk mendorong Syaharie Jaang memimpin dua periode kini sudah mulai tercium". Wartawan memilih topik tersebut secara tidak langsung telah membenarkan bahwa Syaharie Jaang mendapat dukungan untuk memimpin Demokrat Kaltim dua periode. Data (03/01) terdapat partisipan yaitu Syaharie Jaang yang menjadi pusat perhatian pemberitaan. Dilihat dari nada pemberitaan, wartawan lebih banyak membahas Syaharie Jaang mendapat dukungan penuh dari DPC untuk memimpin Demokrat Kaltim dua periode.

Pada data (04/01) dengan judul "Kondisi Politik 2020 Diprediksi Berlangsung Dinamis" di tunjukkan sikap wartawan yang propemerintah.

Di penghujung 2019, kondisi politik Indonesia masih dilihat sebagian masyarakat stagnan. Namun hal tersebut dibantah Plt Dirjen Politik dan Pemerintah Umum yang juga Kepala Pusat Penerangan Kementerian Dalam Negeri (Kemendagri), Bahtiar. Ia memprediksi di tahun 2020 ini, kondisi politik saat ini akan sangat dinamis...(04/01)

Pada data di atas terdapat topik "Di tahun 2020, kondisi politik akan sangat dinamis". Wartawan memilih topik tersebut secara tidak langsung telah memberikan dukungan atas pendapat Bahtiar bahwa kondisi politik Indonesia akan meningkat di tahun 2020. Data (04/01) terdapat partisipan yaitu Bahtiar, Plt Dirjen Politik yang menjadi pusat perhatian pemberitaan. Dilihat dari nada pemberitaan, wartawan lebih banyak mengutarakan pendapat Bahtiar yang memperkirakan bahwa kondisi politik di tahun 2020 akan sangat dinamis karena adanya perbaikan sistem dan pendidikan politik yang berjalan di masyarakat.

Data (05/01) dengan judul "Golkar - PDIP Kian "Mesra"" menunjukkan sikap wartawan yang propemerintah.

"Kemesraan" hubungan komunikasi antara Partai Golkar dengan PDI Perjuangan (PDIP) di level nasional, ternyata hampir pasti juga berimbas ke semua daerah di tanah air. Terutama dalam menyongsong pesta demokrasi Pemilihan Kepala Daerah (Pilkada) serentak September mendatang...(05/01)

Pada data di atas terdapat topik "Kemesraan hubungan komunikasi antara Partai Golkar dengan PDI Perjuangan (PDIP) di level nasional" untuk memberikan dukungan atas hubungan antara kedua Partai yang berimbas ke semua daerah tanah air dalam menyongsong pesta Demokrasi pada September mendatang. Partisipan dalam wacana ini ialah Abdul Kadir yang menjadi pusat perhatian dalam pemberitaan. Dilihat dari nada pemberitaan, wartawan banyak membicarakan tentang pendapat Abdul Kadir mengenai hubungan baik antara Partai Golkan dan PDIP dalam menyongsong Pilkada di bulan September.

Pada data (11/01) dengan judul "Rasyid-Sahidin Hampir Pasti Berpasangan" menunjukkan sikap wartawan yang propemerintah.

Figur-figur yang akan bertarung di Pemilihan Kepala Daerah (Pilkada) Paser September mendatang terus bermunculan. Bahkan peta politik siapa yang akan berpasangan dengan siapa juga perlahan sudah mulai terkuak kini. Di antaranya yang belakangan ramai diperbincangkan adalah Abdul Rasyid yang akan berpasangan dengan Sahidin. Bahkan keduanya dikabarkan sudah hampir pasti diusung Partai Demokrat...(11/01)

Pada data di atas terdapat topik "Belakangan ramai diperbincanngkan Abdul Rasyid yang akan berpasangan dengan Sahidin"memberikan dukungan terhadap pasangan Abdul Rasyid dan Sahidin untuk diusung Partai Demokrat pada Pemilihan Kepala Daerah September mendatang. Partisipan dalam wacana ini ialah Abdul Rasyid dan Sahidin yang menjadi pusat perhatian dalam pemberitaan. Dilihat dari nada pemberitaan, wartawan banyak membicarakan tentang pendapat Abdul Rasyid yang ingin berjuang bersama Sahidin karena dirasa memiliki visi-misi yang sama, serta elektabilitas dan kapasitas yang sudah sesuai dengan kemauan masyarakat.

Pada data (12/01) dengan judul "PDIP Yakin Menang Pilkada di 44 Wilayah"menunjukkan sikap wartawan yang propemerintah.

Ketua DPP PDI Perjuangan (PDIP), Djarot Saiful Hidayat meyakini kandidat yang diusung partainya bisa memenangkan sebanyak 44 dari 270 wilayah yang menggelar Pilkada serentak 2020...(12/01)

Pada data di atas terdapat topik "Djarot Saiful Hidayat meyakini kandidat yang diusung partainya bisa memenangkan sebanyak 44 wilayah". Wartawan memilih topik tersebut secara tidak langsung telah memberikan dukungan atas menangnya PDIP di 44 wilayah. Partisipan dalam wacana ini ialah Djarot Saiful Hidayat yang menjadi pusat perhatian dalam pemberitaan. Dilihat dari nada pemberitaan, wartawan banyak membicarakan tentang pendapat Djarot Saiful 
Hidayat yang optimis akan menang Pilkada di 44 Wilayah.

Pada data (15/01) dengan judul "Ancha Resmi Gandeng Markus" menunjukkan sikap wartawan yang propemerintah.

Bakal Calon (Bacalon) Wali Kota Samarinda, Parawansa Assoniwora Selasa (14/1) kemarin akhirnya mendeklarasikan pasangannya yang akan maju bersamanya di jalur independen pada Pemilihan Kepala Daerah (Pilkada) September mendatang. Dialah Markus Taruk Allo yang akan mendampingi Ancha sapaan akrab Parawan Assoniwora- sebagai Bacalon Wakil Wali Kota (Wawali)...(15/01)

Pada data di atas terdapat topik "Akhirnya Ancha mendeklarasikan pasangannya yang akan maju bersamanya di jalur independen"memberikan dukungan terhadap pasangan Parawansa Assoniwora dan Markus Taruk Allo untuk maju bersama di jalur independen pada pemilihan Kepala Daerah September mendatang. Partisipan dalam wacana ini ialah Parawansa Assoniwora dan Markus Taruk Allo yang menjadi pusat perhatian dalam pemberitaan. Dilihat dari nada pemberitaan, wartawan banyak membicarakan tentang pendapat Ancha yang yakin duet politiknya bersama Markus akan berhasil karena keduanya mewakili kaum muda dan kaum tua.

Pada data (27/01) dengan judul "Ini Alasan Darlis Gandeng Ulama di Pilkada Kukar"menunjukkan sikap wartawan yang propemerintah.

Ketua DPW Partai Amanat Nasional (PAN) yang juga Bacalon Bupati Kukar itu memilih untuk berpasangan dengan $\mathrm{KH}$ Abu Ali. Darlis mengaku memiliki banyak chemistrydan kesamaan visi dengan $\mathrm{KH}$ Abu Ali...(27/01)

Data (27/01) di atas menunjukkan wartawan menggunakan topik "Darlis mengaku memiliki banyak chemistrydan kesamaan visi dengan $\mathrm{KH}$ Abu Ali" secara tidak langsung membenarkan bahwa Darlis dan KH Abu Ali cocok untuk berpasangan dalam Pilkada dan memiliki kesamaan visi. Partisipan dalam wacana ini ialah Darlis dan KH Abu Ali yang menjadi pusat perhatian dalam pemberitaan. Dilihat dari nada pemberitaan, wartawan banyak membicarakan tentang alasan Darlis gandeng KH Abu Ali dalam Pilkada.

Perspektif promasyarakat merupakan sudut pandang dalam melihat suatu peristiwa yang didasari oleh nilai-nilai keyakinan, ide-ide, dan pandangan dari masyarakat. Wartawan memberitakan suatu peristiwa menggunakan perspektif pro masyarakat, maka wartawan tersebut mempunyai sikap mendukung, memihak, simpati, senang terhadap apa yang sedang dilakukan masyarakat dalam peristiwa tersebut. Berikut ini beberapa kutipan dari data.

Pada data (02/01) dengan judul "Pilkada Sedot Anggaran Setengah Triliun" menunjukkan sikap wartawan yang promasyarakat.

...Pengamat Politik Universitas Kutai Kartanegara, Zulkifli berharap menyoroti besarnya pembiayaan Pilkada tersebut. Dengan anggaran lebih dari setengah triliun, mestinya pesta demokrasi itu menghasilkan pemimpin yang berkualitas. "Kalau tidak, maka semua yang dikeluarkan akan sia-sia," kata Zulkifli di hubungi Koran Kaltim tadi malam...(02/01)

Data $(02 / 01)$ di atas menunjukkan wartawan menggunakan topik "Pengamat Politik Universitas Kutai Kartanegara, Zulkifli berharap menyoroti besarnya pembiayaan Pilkada" secara tidak langsung memberi dukungan terhadap masyarakat yang diwakili oleh pengamat politik dari Universitas Kutai Kartanegara, Zulkifli untuk menyorot anggaran jelang Pilkada. Partisipan dalam pemberitaan ini adalah Zulkifli. Dilihat dari nada pemberitaan wartawan lebih banyak membicarakan pernyatan dan tindakan dari Zulkifli yang menyorot anggaran jelang Pilkada agar bisa ditekan dengan melakukan evaluasi.

Pada data (13/01) dengan judul "Soroti Netralitas ASN Jelang Pilkada" menunjukkan sikap wartawan yang pro masyarakat.

Pengamat Hukum dari Universitas Mulawarman (Unmul), Herdiansyah Hamzah menyorot masalah netralitas Apatur Sipil Negara (ASN) jelang Pemilihan Kepala daerah (Pilkada) serentak September mendatang. Termasuk ada ASN yang hendak maju sebagai kandidat pada Pilkada nanti. Secara normatif kata dia, pasal 7 ayat (2) huruf $\mathrm{T}$ Undang-Undang (UU) Nomor 10/2006 tentang Pilkada secara tegas mengisyaratkan kewajiban mundur bagi ASN berlaku setelah ditetapkan sebagai pasangan calon (paslon).Namun menurut dia, tarik menarik kepentingan politik itu bukan hanya soal norma, tetapi juga menyangkut kode etik.

Data $(13 / 01)$ di atas menunjukkan wartawan menggunakan topik "Pengamat Hukum dari Universitas Mulawarman menyorot masalah netralitas ASN jelang Pilkada" secara tidak 
langsung memberi dukungan terhadap masyarakat yang diwakili oleh pengamat hukum dari Universitas Mulawarman, Herdiansyah Hamzah untuk menyorot ASN jelang Pilkada. Partisipan dalam pemberitaan ini adalah Herdiansyah Hamzah. Dilihat dari nada pemberitaan wartawan lebih banyak membicarakan pernyatan dan tindakan dari Herdiansyah yang menyorot ASN yang telah ditetapkan sebagai paslon untuk wajib mundur.

\section{KESIMPULAN}

Berdasarkan hasil penelitian dan pembahasan bentuk-bentuk ekspresi bahasa dan perspektif wacana berita politik surat kabar Koran Kaltim, dapat disimpulkan sebagai berikut: Bentuk ekspresi bahasa wacana berita politik surat kabar Koran Kaltim Januari 2020 ini ialah modalitas dan metafora. Modalitas merupakan komentar atau sikap yang diberikan oleh penulis terhadap suatu hal yang dilaporkan, yaitu keadaan, peristiwa, dan tindakan. Metafora merupakan suatu bentuk analogi yang membandingkan dua hal secara langsung tanpa kata pembanding eksplisit dengan cara penyampaian gagasan teknik tidak langsung, yang dipakai oleh partisipan atau suatu peristiwa tertentu yang ada dalam kalimat. Analogi yang dipakai tersebut menunjukkan penilaian terhadap kata yang menjadi pembanding. Kata yang menjadi penanda metafora menandakan sikap dan penilaian dari wartawan surat kabar Koran Kaltim terhadap objek yang diberitakan. Penilaian yang baik atau buruk, sikap simpati atau antipati serta berpihak atau tidaknya seorang wartawan terhadap suatu peristiwa yang sedang terjadi ini ditunjukkan dengan pemakaian metafora. Perspektif wacana berita politik surat kabar Koran Kaltim Januari 2020 meliputi perspektif promasarakat, dan perspektif propemerintah. Dalam mengungkap perspektif surat kabar Koran Kaltim wartawan menggunakan topik, partisipan, dan nada pemberitaan.

\section{REFERENCES}

Abdurahman. 2011. "Teori Modalitas sebagai Materi Pembelajaran Bahasa Indonesia". Jurnal Bahasa dan Seni. Vol. 12. Hal. 1-9.

Azzuhri, M. 2015. Bahasa, Kuasa, dan Etnisitas. STAIN Pekalongan Press. Pekalongan.

Darma, Y. 2009. Analisis Wacana Kritis. Yrama Widya. Bandung.

Eriyanto. 2011. Analisis Wacana Pengantar Analisis Teks Media. PT. LKIS Printing Cemerlang. Yogyakarta.
Haula, B., dan Nur, T. 2010. "Konseptualisasi Metafora Dalam Rubrik Opini Kompas: Kajian Semantik Kognitif". Jurnal Bahasa dan Sastra. Vol. 12. Hal. 25-35.

Hutagalung, D. 2004. "Hegemoni, Kekuasaan, dan Ideologi”. Jurnal Pemikiran Sosial, Politik dan Hak Asasi Manusia. Vol. 03. Hal. 1-17.

Ibrahim, S., dan Latif, Y. 2018. Bahasa dan Kekuasaan. Mizan. Bandung. Jorgensen, W., dan Phillips, J. 2010. Analisi Wacana Teori dan Metode. Pustaka Pelajar. Yogyakarta.

Jazeri, M. 2010. "Menabur Bahasa, Menuai Kuasa". Jurnal Lingua Scientia. Vol 2. Hal. 101-113.

Mashun. 2005. Metode Penelitian Bahasa. PT Raja Grafindo. Jakarta. Muslich, M. 2008. "Kekuatan Media Massa Mengonstruksi Realitas". Jurnal Bahasa dan Seni. Vol 2. Hal. 150-157

Muhammad. 2014. Metode Penelitian Bahasa. ArRuzz Media. Yogyakarta. Moleong, J. 2017. Metodologi Penelitian Kualitatif. PT Remaja Rosdakarya. Bandung.

Nisa, K. 2017. “Analisis Wacana Kritis (Teori Van Dijk Dalam Kajian Teks Media Massa Pada E-Paper Analisa Medan Rubrik Surat Pembaca)". Jurnal Dialog. Vol. 07. Hal. 557564.

Oktavia, Y., dan Silitonga, F. 2016. "Implementasi Analisis Wacana Kritis Prespektif Leeuwen Dalam Berita Politik Surat Kabar Padang Ekspres Terhadap Pembelajaran Bahasa Berbasis Teks". Jurnal E-ISSN. Vol. 01. Hal. 201-213.

Rijal, S. 2019. "Pemberitaan Media Online Tentang Kaltim Green: Kajian Ekolinguistik Kritis”. Prosiding Seminar Nasional Bahasa, Sastra, dan Seni. Fakultas Ilmu Budaya Universitas Mulawarman. E-ISSN. Vol. 05. Hal. 385-398.

Ridhani, A. 2012. Wacana Argumentasi Tulis. Skripsi. Universitas Negeri Malang. Malang.

Santoso, P. 2016. "Konstruksi Sosial Media Massa". Jurnal Al-Balagh. Vol. 01. Hal 3048.

Schiffirin, D. 2007. Ancaman Kajian Wacana. Pustaka Pelajar. Yogyakarta. Sobur, A. 2012. Analisis Teks Media. PT Remaja Rosdakarya. Bandung.

Suharyono, S., dan Amin, F. 2014. "Bahasa dan Ideologi: Mengungkapkan Ideologi Dan Kekuasaan Simbolik Di Balik Penggunaan Bahasa". Jurnal Humanika. Vol. 19. Hal. 4258.

Sumarti, E. 2010. “Analisis Wacana Kritis Strategi Politik Penggunaan Bahasa Dalam Pidato 
Jihan A., Widyatmike G.M., Syamsul Rijal. - Analisis Wacana Kritis Berita Politik dalam Surat Kabar

Presiden Susilo Bambang Yudhoyono".

Jurnal Litera. Vol. 09. Hal. 19-39.

Suroso. 2002. Bahasa Jurnalistik Perspektif Berita

Utama Politik Surat Kabar Indonesia pada

Awal Era Reformasi (1999). Disertasi.

Universitas Negeri Jakarta. Jakarta. 